\title{
Lung Cancer, Women (Subset of Total Lung)
}

National Cancer Institute

\section{Source}

National Cancer Institute. Lung Cancer, Women (Subset of Total Lung). NCI Thesaurus.

Code C19190.

Budget category. 